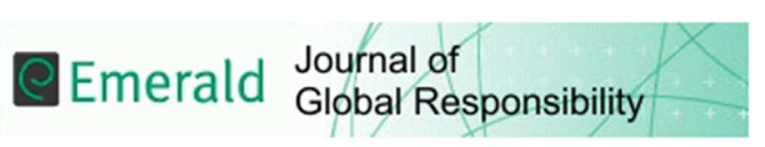

\title{
Ethical communication on society issues: a story from Indonesia
}

\begin{tabular}{|r|l|}
\hline Journal: & Journal of Global Responsibility \\
\hline Manuscript ID & Draft \\
\hline Manuscript Type: & Refereed Article \\
\hline Keywords: & $\begin{array}{l}\text { society disclosures, Indonesia, ethical stakeholder theory, Global Reporting } \\
\text { Initiative }\end{array}$ \\
\hline \multicolumn{2}{|r}{} \\
\hline
\end{tabular}

SCHOLARONE ${ }^{\text {m }}$

Manuscripts 


\title{
Ethical communication on society issues: a story from Indonesia
}

\begin{abstract}
Purpose - This study aims to examine Indonesian Stock Exchange (IDX) listed companies' society disclosures.

Design/methodology/approach - Year-ending 2012 annual report disclosures of 75 IDX listed companies are analyzed. The widely acknowledged Global Reporting Initiative (GRI) guidelines are used as the disclosure index checklist.

Findings: The results show a relatively low level of voluntary society disclosure $(40.27$ percent). The highest level of communication is for issues related to Society programs. Very few companies disclosed information about Public policy, Donations to political parties and Actions taken in response to corruption incidents. Statistical analysis reveals that company size is a positively significant predictor of 'society' communication. Ethical stakeholder theory partially explains the variability of these disclosures.

Research limitations/implications: The main implication of the findings is that Indonesian companies are not involved in the public policy making process. Companies also probably attempt to hide certain information regarding corruption issues to protect their image and reputation.

Originality/value: This paper provides insights into the disclosure practices of society issues, a specific social disclosure theme which is rarely examined in prior literature, within the framework of ethical stakeholder theory. The research also includes corruption issues to be investigated in the disclosure analysis.

Keywords: Society disclosures, Indonesia, ethical stakeholder theory, Global Reporting Initiative

Paper type: Research paper
\end{abstract}




\section{Introduction}

It is widely known that, in the concept of sustainability, corporations' operations will be sustainable if they do not only focus on economic or financial aspects but also focus on the environmental and social aspects (Epstein and Buhovac, 2014). The global business community and scholars currently realize that businesses do have impacts on the social system within which it operates, including the local community. When there is no harmony between businesses and the local community, it is logical to assume that the sustainability of those businesses is threatened. This potentially happens everywhere around the globe, particularly in developing countries in which there are usually huge gaps between the reach and the poor people.

Conflicts between companies and the local community present when there is no good communication between the two, or when companies do not 'pay attention' to the surrounding 'neighbours'. On 26 March 2013, for instance, a big demonstration done by the local community in Dumai ${ }^{1}$ occurred, demanding PT Pelindo ${ }^{2}$ to actively contribute to the local community's activities and development as well as to share parts of its profits to help improve the economy of the local community (Dumaione, 2013). Arguably, there is a greater probability for such conflicts to occur in countries like Indonesia because there are many people living surrounding corporations. Moreover, in countries in which the level of collectivism ${ }^{3}$ is high (see The Hofstede Centre, 2014), conflicts between companies and the local communities potentially occur when those companies do not involve with the local communities' social activities such as local communities' regular meetings and voluntary works. In such countries, people are not individualistic and social relationships among people as well as social communication are considered extremely important.

This paper aims to investigate Indonesia Stock Exchange (IDX) listed companies' society disclosure practices and the factors affecting those practices. In this paper, society disclosure can be defined as any communicated information regarding companies' 
activities and commitment in managing the social impacts of their operations on the society encompassing issues of Local Communities, Corruption, Public Policy, AntiCompetitive Behaviour, and Compliance (see Global Reporting Initiative, 2011).

Indonesia is chosen to be examined because the economy of this developing county looks significantly improving, placing this country into the $10^{\text {th }}$ largest economy in the world in 2014 according to a recent World Bank affiliated report (The Jakarta Post, 2014), but, in fact, it still has complex social problems. In terms of corruption, for instance, this country is categorized as a country having a great number of corruption cases (Transparency International, 2014). In 2013, for instance, the Indonesian national police deals with 1,343 corruption cases (Perdana, 2013). Commentators and scholars argue that corruption even become a culture in Indonesia (see Lellolsima, 2014).

\begin{abstract}
Corporations, which in fact contribute to the improvement of Indonesia's economy, are expected to help the government in solving the above complex social problems. In the context of sustainability, corporations' contribution in solving social problems can be done through corporate social responsibility (CSR). In Indonesia, there are actually regulations requiring companies to undertake CSR activities and report those activities in annual reports. For example, Act No. 40/2007 and Government Regulation No. 47.2012 (Cahaya et al., 2012; Cahaya et al., 2013). However, in those regulations, there are no explanations on what specific CSR items that must be done and reported by companies, except for Employee Benefits disclosure which is regulated under the Indonesian accounting standard (PSAK) No. 24 (IAIGlobal 2014). CSR activities and reporting therefore remain voluntary in this developing country.
\end{abstract}

There are many prior studies examining CSR disclosure practices around the globe, including CSR disclosure practices in Indonesia (e.g. Rahman and Widyasari, 2008; Othman et al., 2011; Trisnawati, 2012). CSR accounting scholars and researchers 
currently focus on more specific CSR issues such as biodiversity reporting (e.g. Van Liempd and Busch, 2013), labour disclosures (e.g. Kent and Zunker, 2013), and health and safety disclosures (e.g. Coatzee and Van Staden, 2011). There are studies on societyrelated disclosures but they focus only on corporate philanthropy (e.g. Ahmad et al., 2009). To contribute to the existing literature, this paper examines society disclosure practices by focusing on local community, corruption, public policy, and anti-competitive behaviour, and compliance issues.

This study contributes to the literature in a number of ways. Firstly, this study focuses on society-CSR disclosure, a specific CSR reporting theme which is rarely examined in prior studies. Most previous studies examine the whole set of CSR disclosures encompassing issues of environment, labour, human rights, society, and product responsibility (e.g. Kamla and Rammal, 2013) or specific environmental issues such as biodiversity (e.g. Khan, 2014). Secondly, this study adopts ethical stakeholder theory, a theory which is rarely used in prior CSR studies. Thirdly, includes corruption issues in the disclosure analysis. Corruption issues are relevant to be examined in Indonesia given that there are many corruption cases in this country, as previously discussed in this section. Corruption issues themselves are rarely investigated in prior CSR accounting studies (see for example Amran and Haniffa, 2011; Othman et al., 2011).

\section{Theoretical framework and hypotheses development}

This study adopts ethical stakeholder theory as the underlying theoretical framework. Stakeholder theory is "an explicitly system-based view of the organization and its environment which recognizes the dynamic and complex nature of the interplay between them" (Gray et al., 1996, 45). Stakeholder theory explains disclosure practices in terms of company and stakeholder relationships (Henderson et al., 2004). This theory has two branches, namely a managerial (organization-centered) branch and an ethical (accountability) branch (Frooman, 1999; Harrison and Freeman, 1999; Guthrie et al., 2004). The managerial branch of stakeholder theory postulates that firms identify 
important groups of stakeholders and seek to manage each group to benefit the firm through disclosure practices (Abeysekera, 2006). The ethical branch of stakeholder theory postulates that all stakeholder groups have a right to be provided with information about how a firm affects them, even if they choose not to use that information, and even if they in turn cannot directly affect the firm (Deegan, 2009).

It is explained in the literature that, within the stakeholder view, there are implicit contracts between society and corporations in relation to any social activities those corporations have done (Brown and Deegan, 1998; Brammer and Pavelin, 2004). Companies therefore have a responsibility to society to act in their bests interests and to provide them with CSR disclosures so that they can evaluate the performance of those companies with respect to the social contracts (Henderson et al., 2004). When companies interact with a greater number of stakeholders, they arguably need to provide information about what they have done to those stakeholders even though some of the stakeholders do not use their right to read that information. This paper argues that all stakeholders, whether they are important or not, must be provided with information about companies' performance, including society-related CSR information, as they have rights to read that information. To best obtain insights about this possible phenomenon and argument, ethical stakeholder theory is employed in this study. Accordingly, several independent variables are hypothesized within the framework of this theory, as explained in the following hypotheses development.

\section{Industry type}

As documented in the literature, industry type can classified into two categories, which are high and low profiles (see Hackston and Milne, 1996; Nurhayati et al., 2006). According to Robert (1992), a high profile industry can be described as an industry which has a high level of sensitivity to the environment and the society, a highly political risk, or a highly competition level. Within the context of ethical stakeholder theory, companies operating in a high profile industry potentially disclose more information than companies operating in a low profile industry do because they deal with more complex issues in their daily operations. Arguably, all of these issues, including society-related CSR information, 
need to be communicated to all stakeholders as they have rights to be provided with that information. Results of prior studies show that high profile companies disclose more CSR-related information (see for example Roberts, 1992; Hackston and Milne, 1996). As such, the following hypothesis is proposed:

\section{H1: There is a positive association between high profile IDX listed companies and the extent of society disclosures in the annual reports}

\section{Company size}

Large companies arguably interact with a greater number of stakeholders in their daily activities. In line with ethical stakeholder theory, it can be said that those stakeholders have the rights to be provided with information regarding companies' performance and activities, including society-related CSR activities. Large companies thus potentially attempt to disclose more information about what they have done as they think they need to ethically satisfy their stakeholders' information rights. A positive relationship between company size and the level of CSR-related disclosures was found in most prior studies (Purushothaman et al., 2000; Brammer and Pavelin, 2004; Gao et al., 2005; Amran and Haniffa, 2011). The following directional hypothesis is thus predicted:

\section{H2: There is a positive association between company size and the extent of society disclosures in the annual reports of IDX listed companies.}

\section{International operations}

Companies internationally usually have more complex social problems to deal with, as these problems may differ across countries. This is because the economies, regulations, culture, and political situations may not be the same across nations (Radebaugh et al., 2006; Epstein and Buhovac, 2014). Companies operating internationally also interact with a greater number of stakeholders that companies operating nationally do. Ethically, companies with international operations potentially attempt to satisfy all those stakeholders by providing more CSR information, including society information, as those stakeholders have the rights to read that information. The information disclosed by multinational companies may reflect a more variety of society information. Past studies 
document the significantly positive association between international operations and CSR-related reporting practices (Zarzeski, 1996; Cahaya et al., 2012). Accordingly, a directional hypothesis is predicted as follows:

\section{H3: There is a positive association between the presence of international operations and the extent of society disclosures in the annual reports of IDX listed companies.}

\section{Economic performance}

Companies with satisfactory financial performance arguably have more sufficient financial resources to undertake CSR activities, including those which are related to the society. Using parts of their profits, for instance, companies may establish community development programs and anti-corruption training programs. Companies which are able to establish and implement those society-related programs potentially communicate the programs to all of their stakeholders, although not all of those stakeholders are interested in the companies' society-related programs. Such a possible phenomenon is in line with the tenet of ethical stakeholder theory. The positively significant association between economic performance and the level of disclosures are documented in several prior studies (see for example Ullman, 1985; Roberts, 1992). The following directional hypothesis is thus proposed:

\section{H4: There is a positive association between the level of economic performance and the extent of society disclosures in the annual reports of IDX listed companies.}

\section{Age of business}

Old companies arguably interact with a greater number of stakeholders than young companies. Within the framework of ethical managerial stakeholder theory, old companies potentially disclose more information, including society-related CSR issues, since there are a greater number of stakeholders having the rights to be provided with information. Roberts (1992) also argues that old companies, which can be considered more mature, are more likely to provide more social information because their histories of involvement in CSR activities are entrenched. Previous studies by Roberts (1992) and 
Hamid (2004) document the positively significant association between age of business and the level of social disclosure practices. A directional hypothesis is again predicted as follows:

\section{H5: There is a positive association between age of business and the extent of society disclosures in the annual reports of IDX listed companies.}

\section{Research approach}

A sample of 75 Indonesia Stock Exchange (IDX) listed companies is randomly selected from a population of 459 for the year ending 2012 (IDX 2014). Data for the dependent and the independent variables are collected from the 75 companies' annual reports. While there is a growing number of companies 'produce' stand-alone sustainability reports in Indonesia, disclosures in such stand-alone reports are not examined in this study. This is because the number of companies publishing stand-alone reports in this nation is still small. According to Kusumaputra (2012), there are only 40 Indonesian companies 'producing' stand-alone sustainability reports in 2012. The use of annual reports as the source of the disclosure data in this study itself is considered appropriate given that such a media is an official form of communication that must be provided by listed companies in Indonesia (see Otoritas Jasa Keuangan, 2014). It has also been widely recognized in the prior literature that annual reports provide highly credible information about companies' activities (Baker and Naser, 2000; Hamid, 2004).

The dependent variable in this study, which is society disclosures, is measured by an unweighted disclosure index. In such a measurement, each disclosure item is deemed equally important and thus each disclosed item is awarded the same score when it is disclosed (Cooke 1991; Meek et al., 1995). A score of 1 (one) is therefore awarded to a sample company when a society disclosure item listed in the disclosure index checklist is disclosed. In contrast, a score of 0 (zero) is awarded when a society disclosure item listed in the checklist is not disclosed. The final disclosure index for each sample company is calculated as the ratio of total score awarded to the company divided by the maximum number of items in the disclosure index checklist (see Cahaya et al., 2012). 
Global Reporting Initiative (GRI) society disclosure items are employed as the disclosure index checklist. GRI guidelines are chosen in this study because these guidelines are regarded as the most widely accepted sustainability guidelines (Albareda, 2013; Epstein and Buhovac, 2014). GRI guidelines themselves are developed and continuously updated through interviews and dialogues with global stakeholders (Global Reporting Initiative, 2014). The use of GRI is therefore reflects the application of companies' ethical stakeholder commitment (Wilburn and Wilburn, 2013) Prior CSR accounting studies in Indonesia have also used these guidelines (e.g. Trisnawati, 2012; Cahaya et al., 2012), highlighting that these guidelines are relevant to be used in an Indonesian setting. To be in line with the financial year examined in this study, which is 2012 financial year, the version of GRI guidelines adopted as the disclosure index checklist is the 2011 one, which is labeled as G3.1 ${ }^{4}$. As such, ten indicators within the category of Society in G3.1 are employed as the disclosure index checklist. The index of each sample company is therefore calculated by dividing the total score of the company's society disclosures with ten. Details of the ten indicators used as the checklist in this study are provided in Appendix.

The independent variables are measured using the measurement approaches mostly used in prior studies (e.g. Hackston and Milne, 1996; Nurhayati et al., 2006; Cahaya et al., 2012). These measurement approaches are presented in Table I.

\section{[Take in Table I]}

\section{Statistical results}

Results of the descriptive statistics for the independent variables are summarized in Table II. It can be seen from the table that total assets ranges widely from 212,446 million Rupiah to 551,336,790 million Rupiah with a mean of $34,840,982.83$ million Rupiah ${ }^{5}$. Return on assets (ROA) also ranges widely from -29.52 percent to 43.08 percent with a mean of 8.64 percent. Compared to the results of prior studies, there appears to be an improvement in the economic performance of Indonesian companies during the last 
decade. In Nurhayati et al. (2006), it was found that the average ROA was 2 percent in 2003. In Cahaya et al. (2012), the average ROA in 2007 was almost 4 percent. In 2012, as shown in Table II, the average ROA was 8.64 percent in 2012. These results may explain the contribution of the private sector in the growth of the Indonesian economy (see Cahaya et al., 2013). According to Allen (2013), the Indonesian economy is booming with the growth of 6 percent per annum. The descriptive statistics further reveals that the average age of IDX listed companies is 37 years old. The oldest company's age in the data set is 97 years old, showing that this company was established before the proclamation of Indonesian independence in 1945.

\section{[Take in Table II]}

As depicted in Table II, 69 percent of sample companies are categorized as high profile whereas 31 percent of sample companies are classified as low profile. It is also shown that 63 percent of sample companies do have international operations while 37 percent of sample companies only operate nationally. There seems to be an increase in the number of companies operating internationally given that previous studies show that most IDX companies do not have international operations. In Cahaya et al. (2008), for instance, it was found that only 33 percent of Indonesian listed companies did have international operations in the 2004 financial year. Such an increase might occur due to the impact of globalization and the rapid development of information technology during the last decade (see Radebaugh et al., 2006; Epstein and Buhovac, 2014).

With regards to the dependent variable, descriptive results (presented in Table III) show that all of the 75 sample companies voluntarily provide society information in their annual reports, with the disclosure level ranging from 20 percent ( 2 items out of ten disclosure items) to 100 percent (all of the ten disclosure items). The average level of society disclosures is 40.27 percent. Therefore, on average, IDX listed companies disclose approximately four voluntary society disclosure items (out of 10 items) in their annual reports. This result indicates that overall society disclosure practices of Indonesian companies are relatively low. 
Figure I presents the variation of disclosure levels across the 10 voluntary society disclosure items by the 75 sample companies. It can be seen from this figure that SO1, Society programs, is the most disclosed item (74 companies, 97.37 percent). This finding suggests that companies in Indonesia have a strong commitment in helping the local communities improve their economy (Tania, 2012). The society programs undertaken by companies may include community development programs, the establishment of entrepreneurship training for the local communities, (see Tania, 2012), training programs for teachers so that their teaching quality can be improved in line with the international teaching standard (Syafrizal, 2012), etc. The implementation of CSR activities such as local community engagement and community development programs signals the presence of synergy among the government, the public and corporations in improving the society's quality of life (see Dharma, 2012). Such synergy is actually the main pillar of CSR implementation and the presence of it is definitely needed in the development process of a country (Perbawani, 2012).

\section{[Take in Figure I]}

The second most disclosed item is SO9 at 92 percent, which is Negative impacts of operations on local communities. This suggests that most IDX listed companies realize that any negative impacts of operations on the society need to be addressed, managed, and communicated. Such practices need to be undertaken so that the dynamic relationship between companies and stakeholders can be well managed. From the lens of stakeholder theory, the harmony between companies and their stakeholders 'guarantees' the sustainability and the future of companies' operations (see Roberts, 1992; Deegan, 2009). It can therefore be said that IDX listed companies have understood this stakeholder concept and apply the concept in managing any potential negative impacts of their operations on the local communities. In particular, within the context of ethical stakeholder theory, IDX listed companies then communicate about what they have done 
in addressing those negative impacts to any stakeholders given that each stakeholder has the rights to be provided with information.

The third most disclosed item is SO10 at 42.67 percent, which is Prevention and mitigation measures implemented in operations. While IDX listed companies attempt to identify and address potential or actual negative impacts on local communities as disclosed through SO9 disclosures, they perhaps cannot optimally prevent and mitigate all of those negative impacts. This is because they have insufficient financial and human resources to do so, or perhaps they have minimum knowledge on how to best prevent those negative impacts (see Lako, 2011). This might explain the finding in relation to the disclosures of SO10 where only 42.67 percent of sample companies provide such disclosures in their annual reports.

Interestingly, Figure I shows that Public policy (SO5) is the least disclosed item at 4 percent. This is followed by Donations to political parties and related institutions (SO6) at 14.67 percent and Actions taken in response to corruption incidents (SO4) at 16 percent. One possible explanation for the small percentage of companies disclosing SO5 is that those companies are not involved in the public policy development. This might be because the government does not ask or invite companies to participate in the public policy development. Alternatively, corporations themselves does not actively criticize the government's public policy or even do not respond the government's 'invitation' to participate in the public policy development.

A possible explanation for the small percentage of IDX listed companies disclosing Donations to political parties and related institutions (SO6) is that the 2012 financial year is not a period of the general election in Indonesia. The general election itself would be undertaken in $2014^{6}$. It is therefore logical that there are only few companies giving donations to political parties or politicians. The number of companies giving donations to political parties or politicians usually increases significantly within the political campaign period before the general election (see Manurung, 2013).. 
The low disclosures of Actions taken in response to corruption incidents (SO4) can be explained by the argument that directors of Indonesian companies attempt to hide corruption cases occurring in their companies from the eyes of the public. This is because they assume such cases will threaten the companies' image and reputation. The corruption cases may be solved internally but are not disclosed in the annual reports.

Hypotheses 1 to 5 were tested by using multiple regression technique. Classical assumptions of multiple regression ${ }^{7}$, consisting of multicollinearity, normality, outliers, and homoscedasticity (see Hair et al., 1998), have been checked and it was found that all of the assumptions were met. The results of multiple regression analysis can therefore be deemed truly representative of the sample (see Hair et al., 1998) and are summarized in Table IV.

\section{[Take in Table IV]}

It can be seen from Table IV that the regression model is highly significant (p-value 0.002). The value of adjusted R-square is 0.178 . The variation of voluntary society disclosure practices is explained by the variation of one highly significant predictor $(p$ value is smaller than 1 percent significance level), being company size. The coefficient of this independent variable is positive, supporting the argument presented in Section 2 which posits that there is a positive association between company size and voluntary society disclosure practices (Hypothesis 2). The other hypothesized variables (industry type, international operations, economic performance, and age of business) are not significant and thus they are regarded unable to explain the variation of voluntary society disclosure practices in Indonesia.

\section{Discussion and Conclusion}

In summary, while all of the sample companies communicate at least two items, there is a relatively low level of society disclosure practices (40.27 percent) by IDX listed companies. Most companies might not be involved in the public policy making process and therefore only 4 percent of sample companies disclose public policy issues. Most 
companies might not provide donations for political parties as the 2012 financial year is not a campaign period, and thus only 4 percent of sample companies disclose issues related to donations for political parties. It is important to note, however, that there is a small number of companies disclose corruption issues, which are arguably sensitive. Companies probably attempt to hide certain information regarding corruption issues as they have a high level of corruption risks, do not have sufficient anti-corruption training, and do not seriously respond to corruption incidents. They perhaps do seriously respond to corruption incidents but attempt to hide the incidents from the eyes of the public.

The explanation regarding the small number of companies disclosing corruption-related issues above is arguable given that there are a lot of corruption cases in Indonesia. Based on the survey undertaken by Transparency International ${ }^{8}$, Indonesia was ranked 114 among 177 corrupt countries worldwide in 2013 (see Transparency International, 2014), highlighting that this country has serious problems with corruptions. Corruption cases themselves occur in not only the public sector but also the private sector. One of the examples is the corruption done by the Commercial Banking Centre Manager of PT Bank Mandiri Tbk ${ }^{9}$, Rudi Wibisono. Rudi was found guilty by the Indonesian Supreme Court because of the corruption he did through a fictitious credit amounting to almost about 43 billion rupiah. He was finally arrested on 3 December 2013 by the Indonesian Attorney General Office (Heru, 2013; Nurokhman, 2013).

Industry type was found to be insignificant. This finding is consistent with Brown et al. (2005) and Cahaya et al. (2012). This insignificant statistical result is possibly explained by the argument that low profile companies have the same commitment as high profile companies do in undertaking society-related CSR, although low profile companies might deal with less complex social issues in their daily operations. While high profile companies attempt to manage the negative impacts of their operations on local communities, for example, low profile companies such as banks might do the same thing as they think their daily operations also potentially have negative impacts on local communities such as causing traffic jams on the streets around those banks' buildings. 
Accordingly, a variation of society disclosure levels between high and low profile companies was not found in this study.

An important finding of this study was that company size was a positively significant predictor of voluntary society disclosure practices. This is consistent with Gao et al. (2005) and Amran and Haniffa (2011) and supports Hypothesis 2 that bigger companies disclose more information about society issues in their annual reports. One explanation for this positively significant relationship is that larger Indonesian companies interact with a greater number of stakeholders. In line with ethical stakeholder theory, large companies assume that there are a lot of stakeholders who have the rights to be provided with society-related information, even though not all of those stakeholders need or will use that information. Larger companies in Indonesia therefore attempt not to violate these stakeholders' rights by providing more society information.

This study found that international operations does not significantly affect the level of society disclosures. This is interesting given that global stakeholders currently consider CSR, including society-related CSR, as one of the main bases in making economic decisions. Epstein and Buhovac (2014), for instance, note that, global investors currently look for companies undertaking good CSR practices. Creditors worldwide currently tend to lend their money to companies having strong sustainability commitments (Epstein and Buhovac, 2014). These stakeholders groups are therefore currently labeled as 'social investors and social creditors' (see Epstein and Buhovac, 2014). The insignificant relationship between international operations and society disclosure practices is possibly explained by the argument that companies operating internationally may have difficulties in interacting with the local communities overseas as well as in participating in public policy making. This is because there are differences in culture, social problems, regulations, economy, and political systems across nations (see Epstein and Buhovac, 2014). Accordingly, there are not many society-related CSR activities that can be performed by Indonesian companies operating internationally and, as a result, there is little society information that can be disclosed by those companies. 
Similar to international operations, economic performance was found to be insignificant. This finding is consistent with Purushothaman et al. (2000). One possible reason is that companies with satisfactory financial performance use their excess money to expand their business by, for instance, opening new branches, improving their information technology (IT) infrastructure, recruiting new experienced managers, etc. A report from IndonesiaInvestments (2014) indicates that Indonesian private sector seriously attempt to expand their business so that they are ready to compete with competitors nationally and internationally and can further contribute to the improvement of the Indonesian economy. Thus, at present, society-related CSR practices may not be put as the main priority by Indonesian companies having satisfactory financial performance.

Age of business was also found to be insignificant. One possible explanation for this insignificance is that younger companies do have sufficient and good knowledge in relation to society-related CSR and therefore they undertake similar society-related CSR activities and disclose these activities in their annual reports. Old companies might have more experience in dealing with the society but young companies may also quickly learn from what old companies do. The governance compositions of young companies themselves may also be dominated by relatively young managers who potentially have more contemporary business knowledge. Such managers potentially have good knowledge regarding CSR, which is a relatively new ${ }^{10}$ business concept in Indonesia, and therefore they attempt to implement CSR practices, including society-related CSR practices, in the companies' daily operations as well as communicate those practices in the annual reports.

Overall, Indonesian listed companies voluntarily provide a relatively low level of society disclosures. It is found that the variability of society disclosures is partially explained by ethical stakeholder theory. The lack of disclosure may be explained by the argument that companies are not involved in the public making process and the possibility that companies attempt to hide information regarding corruption from the eyes of stakeholders. The Indonesian general election is not undertaken in 2012 therefore there is a small number of companies disclose information about donations for political parties. 
This study provides important contributions to the literature by offering additional knowledge regarding the positively significant effect of company size on the level of society disclosure practices in Indonesia.

As with most research, this study has limitations. Firstly, this study focuses only on disclosures in annual reports, not in other media such as stand-alone sustainability reports. This is because an annual report is the official communication media that must be provided by a listed company annually. Secondly, this study focuses only on the quantity of society information, not on the quality. Future society-related CSR disclosure studies should therefore analyze disclosures in stand-alone sustainability reports (if there are a sufficient number of companies 'producing' such reports to be statistically analyzed) and examines the quality of society disclosure practices in Indonesia. 


\section{References}

Abeysekera, I. (2006), "The project of intellectual capital disclosure: researching the research", Journal of Intellectual Capital, Vol. 7 No. 1, pp. 61 - 77.

Ahmad, A.R., Tower, G.D. and Van der Zahn, J.M. (2009), "Exploratory analysis of corporate philanthropy disclosure practices and influencing factors in Australia", Financial Reporting Regulation and Governance, Vol. 16 No. 2, pp. 103-121.

Albareda, L. (2013). "CSR governance innovation: standard competition-collaboration dynamic", Corporate Governance, Vol. 13 No. 5, pp. 551-568.

Allen, D. (2013), "Indonesia: the next Asian giant", available at: http://www.itbdigital.com/opinion/2013/03/07/indonesia-the-next-asian-giant/ (accessed 8 July 2013).

Amran, A. and Haniffa, R.M. (2011), "Evidence in development of sustainability reporting: a case of a developing country", Business Strategy and the Environment, Vol. 20 No. 3, pp. 141-156.

Baker, A. and Naser, K. (2000), "Empirical evidence on corporate social disclosure (CSD) practices in Jordan", International Journal of Commerce \& Management, Vol. 10 No. $3 / 4$, pp. 18-34.

Bank Mandiri. (2014), "Currency", available at: http://www.bankmandiri.co.id/english/resource/kurs.asp?row=2 (accessed 22 June 2014).

Brammer, S. and Pavelin, S. (2004), "Voluntary social disclosures by large UK companies", Business Ethics: A European Review, Vol. 13 No. 2/3, pp. 86-99.

Brown, A.M., Tower, G. and Taplin, R. (2005), "Human resources disclosures in the annual reports of Pacific island countries' entities", Asia Pacific Journal of Human Resources, Vol. 43 No. 2, pp. 252-272.

Brown, N. and Deegan, C. (1998), "The public disclosure of environmental performance information -- a dual test of media agenda setting theory and legitimacy theory", Accounting and Business Research, Vol. 29 No. 1, pp. 21-41.

Cahaya, F.R., Porter, S., Tower, G. and Brown, A. (2013), "Coercive pressure by the Indonesian government on labour disclosures: conflicting interests?", paper presented at the twelfth Australasian Conference on Social and Environmental Accounting Research, Hamilton, 1-3 December.

Cahaya, F.R., Porter, S.A. and Brown, A.M. (2008), "Social disclosure practices by Jakarta Stock Exchange listed entities", Journal of the Asia-Pacific Centre for Environmental Accountability, Vol. 14 No. 1, pp. 2-11.

Cahaya, F.R., Porter, S.A., Tower, G. and Brown, A. (2012), "Indonesia's low concern for labour issues", Social Responsibility Journal, Vol. 8 No. 1, pp. 114-132.

Coatzee, C.M. and Van Staden, C.J. (2011), "Disclosure responses to mining accidents: South African evidence", Accounting Forum, Vol. 35, pp. 232-246.

Cooke, T.E. (1991), "An assessment of voluntary disclosure in the annual reports of Japanese corporations", The International Journal of Accounting, Vol. 26 No. 3, pp. 147-189.

Deegan, C. (2009), Financial Accounting Theory, 3rd ed, McGraw-Hill, Sydney.

Dharma, C.A. (2012), "Indonesia berprestasi: CSR dunia industri", in N. Prajarto (Ed.), CSR Indonesia: Sinergi Pemerintah, Perusahaan dan Publik, Fisipol UGM, Yogyakarta, pp. 239-259. 
Dumaione. (2013), "Dituding tak peduli rakyat Pelindo Dumai didemo warga", available at: http://riauone.com/news/detail/116/\#.U6IHofmSxnk (accessed 19 June 2014).

Epstein, M.J. and Buhovac, A.R. (2014), Making Sustainability Work: Best Practices in Managing and Measuring Corporate Social, Environmental, and Economic Impacts, 2nd ed, Greenleaf Publishing Limited, Sheffield.

Frooman, J. (1999), "Stakeholder influence strategies", The Academy of Management Review, Vol. 24 No. 2, pp. 191-205.

Gao, S.S., Heravi, S. and Xiao, J.Z. (2005), "Determinants of corporate social and environmental reporting in Hong Kong: a research note", Accounting Forum, Vol. 29 No. 2, pp. 233-242.

Global Reporting Initiative. (2011), Sustainability Reporting Guidelines, GRI, Amsterdam, available

at: http://www.globalreporting.org/NR/rdonlyres/53984807-9E9B-4B9F-B5E877667F35CC83/0/G31GuidelinesinclTechnicalProtocolFinal.pdf (accessed 19 May 2011).

Global Reporting Initiative. (2014), available at: http://www.globalreporting.org (accessed 4 June 2014).

Gray, R., Owen, D. and Adams, C. (1996), Accounting and Accountability: Changes and Challenges in Corporate Social and Environmental Reporting, Prentice Hall, London.

Guthrie, J., Petty, R., Yongvanich, K. and Ricceri, F. (2004), "Using content analysis as a research method to inquire into intellectual capital reporting", Journal of Intellectual Capital, Vol. 5 No. 2, pp. 282-293.

Hackston, D. and Milne, M..J. (1996), "Some determinants of social and environmental disclosures in New Zealand companies", Accounting, Auditing \& Accountability Journal, Vol. 9 No. 1, pp. 77-108.

Hair, J.F., Anderson, R.E., Tatham, R.L. and Black, W.C. (1998), Multivariate Data Analysis, 5th ed, Prentice-Hall, New Jersey.

Hamid, F. (2004), "Corporate social disclosure by banks and finance companies: Malaysian evidence", Corporate Ownership \& Control, Vol. 1 No. 4, pp. 118130.

Harrison, J.S. and Freeman, R.E. (1999), "Stakeholders, social responsibility, and performance: empirical evidence and theoretical perspectives", The Academy of Management Journal, Vol. 42 No. 5, pp. 479-485.

Henderson, S., Peirson, G. and Harris, K. (2004), Financial Accounting Theory, Pearson Prentice Hall, Frenchs Forest.

Heru. (2013), "Bank Mandiri official arrested over fictitious credit application", available at: http://www.antaranews.com/en/news/91685/bank-mandiri-official-arrestedover-fictitious-credit-application (accessed 22 June 2014).

IAIGlobal. (2014), available at: http://www.iaiglobal.or.id (accessed 20 June 2014).

IDX. (2014), available at: http://www.idx.co.id/ (accessed 22 June 2014).

Indonesia-Investments. (2014), "Masterplan for acceleration and expansion of Indonesia's economic development", available at: http://www.indonesiainvestments.com/projects/government-development-plans/masterplan-foracceleration-and-expansion-of-indonesias-economic-development-mp3ei/item 306 (accessed 22 June 2014). 
Kamla, R. and Rammal, H.G. (2013), "Social reporting by Islamic banks: does social justice matter?", Accounting, Auditing \& Accountability Journal, Vol. 26 No. 6, pp. 911-945.

Kent, P. and Zunker, T. (2013), “Attaining legitimacy by employee information in annual reports", Accounting, Auditing \& Accountability Journal, Vol. 26 No. 7, pp. 10721106.

Khan, T. (2014), "Kalimantan's biodiversity: developing accounting models to prevent its economic destruction", Accounting, Auditing \& Accountability Journal, Vol. 27 No. 1, pp. 150-182.

Kusumaputra, R.A. (2012), “Antam raih penghargaan best website 2012”, available at: http://health.kompas.com/read/2012/12/03/21350969/Antam.Raih.Penghargaan.B est.Website.2012 (accessed 6 June 2014).

Lako, A. (2011), Dekonstruksi CSR \& Reformasi Paradigma Bisnis \& Akuntansi, Erlangga, Jakarta.

Lellolsima, S. (2014), "Samad ajak ribuan kader LDII cegah budaya korupsi”, available at: $\quad$ http://www.rmol.co/read/2014/05/15/155367/Samad-Ajak-Ribuan-KaderLDII-Cegah-Budaya-Korupsi- (accessed 21 June 2014).

Manurung, R.J. (2013), "Demokrat akui dana parpol dari perseorangan dan korporasi”, available at: http://jaringnews.com/politik-peristiwa/umum/40110/demokrat-akuidana-parpol-dari-perseorangan-dan-korporasi (accessed 21 June 2014).

Meek, G.K., Roberts, C.B. and Gray, S.J. (1995), "Factors influencing voluntary annual report disclosures by U.S., U.K. and continental European multinational corporations", Journal of International Business Studies, Vol. 26 No. 3, pp. 555572.

Nurhayati, R., Brown, A. and Tower, G. (2006), "Understanding the level of natural environmental disclosures by Indonesian listed companies", Journal of the Asia Pacific Centre for Environmental Accountability, Vol. 12 No. 3, pp. 4-11.

Nurokhman. (2013), "Mantan manager Bank Mandiri diringkus", available at: http://suaramerdeka.com/v1/index.php/read/news/2013/12/04/181993 (accessed 22 June 2014).

Othman, S., Darus, F. and Arshad, R. (2011), "The influence of coercive isomorphism on corporate social responsibility reporting and reputation", Social Responsibility Journal, Vol. 7 No. 1, pp. 118-135.

Otoritas Jasa Keuangan. (2014), available at: http://www.ojk.go.id/ (accessed 13 May 2014).

Pelindo. (2014), available at: http://www.indonesiaport.co.id (accessed 19 June 2014).

Pemerintah Republik Indonesia. (1995), "Undang-undang Republik Indonesia nomor 8 tahun 1995 tentang pasar modal", available at: http://www.bapepam.go.id/pasar_modal/regulasi_pm/uu_pm/UU\%20No\%208\%2 0Tahun\%201995\%20tentang\%20Pasar\%20Modal.pdf (accessed 23 June 2011).

Perbawani, P.S. (2012), "Rantai pemahaman corporate social responsibility (CSR)", in N. Prajarto (Ed.), CSR Indonesia: Sinergi Pemerintah, Perusahaan dan Publik, Fisipol UGM, Yogyakarta, pp. 19-42.

Perdana, P.P. (2013), “Tahun ini, polisi tangani 1.343 kasus korupsi di Indonesia", available

at: 
http://regional.kompas.com/read/2013/12/09/2149122/Tahun.Ini.Polisi.Tangani.1. 343.Kasus.Korupsi.di.Indonesia (accessed 21 June 2014).

Purushothaman, M., Tower, G., Hancock, P. and Taplin, R. (2000), "Determinants of corporate social reporting practices of listed Singapore companies", Pacific Accounting Review, Vol. 12 No. 2, pp. 101-133.

Radebaugh, L.H., Gray, S.J. and Black, E.L. (2006), International Accounting and Multinational Enterprises, 6th ed., John Wiley \& Sons, Hoboken.

Rahman, A. and Widyasari, K.N. (2008), "The analysis of company characteristic influence toward CSR disclosure: empirical evidence of manufacturing companies listed in JSX", Jurnal Akuntansi dan Auditing Indonesia, Vol. 12 No. 1, pp. 2535.

Roberts, R.W. (1992), "Determinants of corporate social responsibility disclosure: an application of stakeholder theory", Accounting, Organizations and Society, Vol. 17 No. 6, pp. 595-612.

Syafrizal. (2012), "CSR berwajah Indonesia", in N. Prajarto (Ed.), CSR Indonesia: Sinergi Pemerintah, Perusahaan dan Publik, Fisipol UGM, Yogyakarta, pp. 101127.

Tania, S. (2012), “Corporate Social Responsibility di Indonesia: prinsip dan aplikasi”, in N. Prajarto (Ed.), CSR Indonesia: Sinergi Pemerintah, Perusahaan dan Publik, Fisipol UGM, Yogyakarta, pp. 75-100.

The Hofstede Centre. (2014), available at: http://geert-hofstede.com/countries.html (accessed 21 June 2014).

The Jakarta Post. (2014), "RI 10th-largest economy: WB", available at: http://www.thejakartapost.com/news/2014/05/05/ri-10th-largest-economywb.html (accessed 21 June 2014).

Transparency International. (2014), available at: http://www.transparency.org/country (accessed 21 June 2014).

Trisnawati, R. (2012), "Pengukuran tanggung jawab sosial perusahaan perbankan syariah di Indonesia", Jurnal Akuntansi dan Auditing Indonesia, Vol. 16 No. 2, pp. 103 121.

Types of corporations 2006, available at: http://en.wikipedia.org/wiki/Types_of_corporations\#Indonesia (accessed 16 August 2006).

Ullman, A.A. (1985), "Data in search of a theory: A critical examination of the relationship among social performance, social disclosure, and economic performance of US firms", Academy of Management Review, Vol. 10 No. 3, pp. 540-557.

Van Liempd, D. and Busch, J. (2013), "Biodiversity reporting in Denmark", Accounting, Auditing \& Accountability Journal, Vol. 26 No. 5, pp. 833-872.

Wilburn, K. and Wilburn, R. (2013), "Using Global Reporting Initiative indicators for CSR programs", Journal of Global Responsibility, Vol. 4 No. 1, pp. 62-75.

Zarzeski, M.T. (1996), "Spontaneous harmonization effects of culture and market forces on accounting disclosure practices", Accounting Horizons, Vol. 10 No. 1, pp. 1837. 


\section{Table I Measurement Technique of the Independent Variables}

\begin{tabular}{|l|l|l||}
\hline \multicolumn{1}{|c|}{$\begin{array}{c}\text { Independent } \\
\text { Variables }\end{array}$} & \multicolumn{1}{|c|}{ Measurement } & $\begin{array}{c}\text { Type of } \\
\text { Data }\end{array}$ \\
\hline Industry & $\begin{array}{l}1=\text { high profile } \\
0=\text { low profile industry }\end{array}$ & Categorical \\
\hline Company size & $\begin{array}{l}\text { Log of total assets } \\
\text { Continuous }\end{array}$ \\
\hline $\begin{array}{l}\text { International } \\
\text { operations } \\
\text { subsidiary or a foreign branch office } \\
\text { No foreign sales, foreign subsidiaries } \\
\text { or foreign branch offices }\end{array}$ & Categorical \\
\hline $\begin{array}{l}\text { Economic } \\
\text { performance }\end{array}$ & Return on Assets (ROA) :2 year average & Continuous \\
\hline Age of business & Number of years from inception & Continuous \\
\hline
\end{tabular}

Source: Original table

Table II Descriptive Statistics of the Independent Variables

\begin{tabular}{|c|c|c|c|c|}
\hline \multicolumn{5}{|c|}{ Panel A: Continuous Variables } \\
\hline Variable & Minimum & Maximum & Mean & $\begin{array}{l}\text { Standard } \\
\text { Deviation }\end{array}$ \\
\hline Company size (million Rupiah) & 212,446 & $551,336,790$ & $34,840,982.83$ & $91,300,659.98$ \\
\hline Economic performance (\%) & -29.52 & 43.08 & 8.64 & 10.68 \\
\hline Age of business (years) & 7 & 97 & 37 & 19 \\
\hline \multicolumn{5}{|c|}{ Panel B: Categorical Variables } \\
\hline Variable & & & & Percentage \\
\hline \multicolumn{5}{|l|}{ Industry type } \\
\hline High profile industry & & & & 69 \\
\hline Low profile industry & & & & 31 \\
\hline \multicolumn{5}{|l|}{ International operations } \\
\hline \multirow{2}{*}{\multicolumn{4}{|c|}{$\begin{array}{l}\text { Yes-Have foreign sales or a foreign subsidiary or a foreign branch office } \\
\text { No foreign sales, foreign subsidiaries or foreign branch offices }\end{array}$}} & 63 \\
\hline & & & & 37 \\
\hline
\end{tabular}

Source: Original table 
Table III Descriptive Statistics of Society Disclosure Practices

\begin{tabular}{||l|c|c|c|c|}
\hline Dependent Variable & $\begin{array}{c}\text { Minimum } \\
(\mathbf{\%})\end{array}$ & $\begin{array}{c}\text { Maximum } \\
\mathbf{( \% )}\end{array}$ & $\begin{array}{c}\text { Mean } \\
\mathbf{( \% )}\end{array}$ & $\begin{array}{c}\text { Standard } \\
\text { Deviation } \\
\mathbf{( \% )}\end{array}$ \\
\hline $\begin{array}{l}\text { Society disclosure index } \\
\text { (\%) of 75 sample } \\
\text { companies }\end{array}$ & 20 & 100 & 40.27 & 21.50 \\
\hline
\end{tabular}

Source: Original table

Table IV Results of Multiple Regression

\begin{tabular}{|l|c|c|c|}
\hline \multicolumn{1}{|c|}{ Variable } & $\begin{array}{c}\text { Predicted } \\
\text { Sign }\end{array}$ & Coefficient & P-value \\
\hline (Constant) & & 0.246 & 0.000 \\
\hline Industry type & + & 0.051 & 0.336 \\
\hline Company size & + & 0.000000000877 & $0.002^{* * *}$ \\
\hline International operations & + & 0.073 & 0.142 \\
\hline Economic performance & + & -0.001 & 0.742 \\
\hline Age of business & + & 0.001 & 0.295 \\
\hline Model Summary & & 0.178 & \\
\hline Adjusted R-Square & \multicolumn{3}{|c|}{0.19495} \\
\hline Standard Error of the Estimate & \multicolumn{3}{|c|}{$0.002^{* * *}$} \\
\hline Regression Model (Sig.)
\end{tabular}

$* * *$ significant at 1 percent level

Source: Original table 
Figure I The 10 Items of Voluntary Society Disclosures

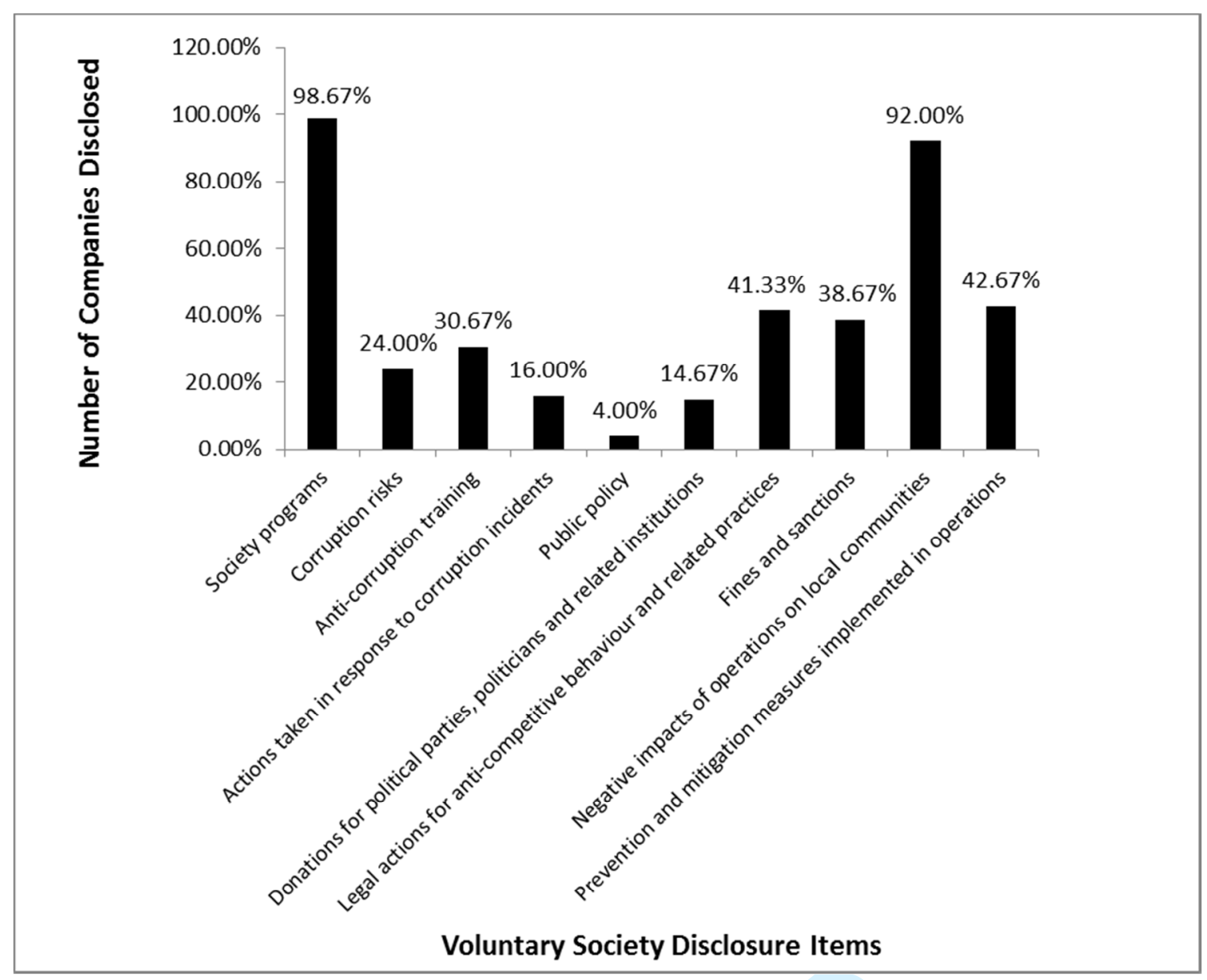

Source: Original figure 


\footnotetext{
${ }^{1}$ Dumai is a city in the Province of Riau, Indonesia. It is located in Sumatera Island.

${ }^{2}$ PT Pelindo is a government owned corporation which is responsible for the governance, regulation, maintenance and operation of harbours and ports in Indonesia (Pelindo, 2014).

${ }^{3}$ Collectivism is a high level of interdependence a society maintains among its members (The Hofstede Centre, 2014). In collectivist countries like Indonesia, people are not individualistic and therefore social relationships among people are considered extremely important.

${ }^{4}$ There is actually a newer version which is labelled as G4 (see Global Reporting Initiative, 2014). This version, however, was released in 2013. As this study examines society disclosures in 2012 annual reports, G4 is considered irrelevant to be used as the disclosure index checklist.

${ }^{5}$ For illustrative purposes, 34,840,982.83 million Rupiah equals to about 2,925 million US Dollars. This currency conversion is calculated based on the value of Rupiah against the US Dollar at the time of the data analysis process of this study (June 20,2014) (see Bank Mandiri, 2014).

${ }^{6}$ The general election in Indonesia is conducted every five year.

${ }^{7}$ The results of assumption test are not shown in this paper for brevity.
} 
${ }^{8}$ Transparency International is an international non-governmental organization that monitors and announces corporate and political corruptions as well as publishes a comparative listing of corruption around the globe (Transparency International, 2014).

${ }^{9}$ PT, Tbk is the abbreviation of Perseroan Terbatas, Terbuka. This abbreviation is usually used for Indonesian listed companies (Types of corporations, 2006). This term refers to an Indonesian stock limited liability company whose shares are owned by at least 300 stockholders and having a paid up capital of at least 300 million Rupiah or a number of shareholders and paid capital stipulated by the Indonesian governmental regulations (Pemerintah Republik Indonesia, 1995).

${ }_{10}$ According to Tania (2012), the concept of CSR became popular in Indonesia in the 2000s. 